\title{
Short communication: Effect of bactofugation of raw milk on counts and microbial diversity of psychrotrophs
}

\author{
José C. Ribeiro Júnior, ${ }^{1 *}$ Gislaine A. S. Peruzi, ${ }^{2}$ Samera R. Bruzaroski, ${ }^{2}$ Ronaldo Tamanini, ${ }^{2}$ \\ Cátia M. O. Lobo, ${ }^{1}$ Bruna Alexandrino, ${ }^{1}$ Ana C. M. Conti, ${ }^{1}$ Amauri A. Alfieri, ${ }^{2}$ and Vanerli Beloti ${ }^{2}$ \\ ${ }^{1}$ College of Veterinary Medicine and Animal Science, Federal University of Tocantins, Araguaína, Tocantins, Brazil, 77.804-970 \\ ${ }^{2}$ National Institute of Science and Technology for the Dairy Production Chain (INCT-Leite), PO Box 10.011, Londrina, Paraná, Brazil, 86.057-970
}

\section{ABSTRACT}

Bactofugation is a centrifugal process for removing spores of microorganisms from milk, especially when it is destined for cheese making. Other microorganisms may be removed in bactofugation. This study aimed to verify the effect of milk bactofugation on the counts and microbial diversity of psychrotrophs. The raw milk was preheated $\left(\approx 55^{\circ} \mathrm{C}\right)$ before being bactofuged, and samples were collected from 3 batches of milk: refrigerated raw, preheated, and bactofuged, representing the immediate conditions before and after bactofugation. The mean psychrotrophic counts of the 3 batches were $3.08( \pm 1.69) \times 10^{6}, 193( \pm 232)$, and $20( \pm 26) \mathrm{cfu} /$ $\mathrm{mL}$, respectively. Preheating was sufficient to eliminate 99.99\% of the raw milk psychrotrophs, but bactofugation further reduced $89.66 \%$ of psychrotrophs from preheated milk. Lysinibacillus fusiformis was the most frequently isolated species $(45.7 \%)$ among the psychrotrophs of raw milk and, proportionally, were more frequent in preheated $(37.5 \%)$ and bactofuged $(60 \%)$ milk. Bacillus invictae (20\%), Enterococcus faecalis (10\%), and Kurthia gibsonii (10\%) were also isolated from bactofuged milk. Albeit in small numbers, psychrotrophic, thermoduric, and spore-forming bacteria with known proteolytic and lipolytic activity remained in the milk after bactofugation, which apparently had no effect on a specific population of microorganisms but proportionally reduced the entire psychrotrophic microbiota of raw milk.

Key words: bactofugation, bacterial count, efficiency, spoilage microorganisms

\footnotetext{
Received December 11, 2018

Accepted May 8, 2019.

*Corresponding author: ribeirojuniorjc@gmail.com or jcribeiro@uft .edu.br
}

\section{Short Communication}

A bactofuge is a piece of equipment used by the dairy industry to reduce the microbial load of milk, especially when milk is of poor quality and intended for cheese production (Gésan-Guiziou, 2010). A bactofuge is a high-speed centrifuge specially designed to remove bacterial spores from milk at high temperatures (Farkye, 2004). The bactofuge centrifuges the milk at approximately $9,000 \times g$ for less than $1 \mathrm{~s}$ at 55 to $60^{\circ} \mathrm{C}$ (GésanGuiziou, 2010), removing the concentrated bactofugate that contains spores (Stack and Sillen, 1998). In addition to sporulated microorganisms, counts of other microorganisms may also be reduced by bactofugation.

Milk psychrotrophs are potentially the major microorganisms responsible for milk deterioration (Sørhaug and Stepaniak, 1997). Lipases and proteases produced by most psychrotrophs significantly reduce the quality and shelf life of pasteurized and UHT fluid milks and dairy products (Dogan and Boor, 2003). Thus, the aim of the present study was to verify the effect of bactofugation of raw milk on the counts and the microbial diversity of psychrotrophs.

For this purpose, 3 different batches of milk were collected at different processing stages: raw, preheated (between 45 and $55^{\circ} \mathrm{C}$ ), and bactofuged, totaling 9 milk samples. Refrigerated raw milk was collected from the bulk tanks. The remaining samples from the batch were collected after the installation and asepsis of sanitary taps in the pipe in the entrance (preheated) and exit of the bactofuge that were hermetically closed. The bactofuge installed in the cheese factory (Padroniza Indústria Brasileira de Pasteurizadores Ltda., Bauru, São Paulo, Brazil) had a force of $10,000 \times g$ with a continuous flow of $10,000 \mathrm{~L} / \mathrm{h}$. The concentrated bactofugate was discarded (less than 1\%). The collections were carried out in September 2017 in a dairy company in the interior of São Paulo State, Brazil. The milk samples were sent under refrigeration to the Laboratory of Inspection of Animal Products of the National Institute of Science and Technology for the Milk Production Chain, 
headquartered at the State University of Londrina, in Paraná State (Brazil). The interval between collection and the microbiological analyses did not exceed $4 \mathrm{~h}$.

Serial decimal dilutions of milk samples were performed in saline solution $(0.9 \%)$, which were seeded in duplicate on the surface of plate count agar (Oxoid, Basingstoke, UK). Plates were incubated at $7^{\circ} \mathrm{C}$ for 10 $\mathrm{d}$. The results of the counts were submitted to nonparametric statistical analyses by $\chi^{2}$ test in SAS software (v. 9.0; SAS Institute Inc., Cary, NC).

After the psychrotrophic bacterial counts, all colonies of one of the duplicate plates were recovered in brain heart infusion broth (Acumedia, Baltimore, MD), purified on plate count agar, and subjected to DNA extraction according to the protocol of Ribeiro Júnior et al. (2016).

All extracts were subjected to amplification of the internal transcribed spacer (ITS) region of 16-23S rRNA using the primers described by Normand et al. (1996) (F: CCGGGTTTCCCCATTCGG) and Edwards et al. (1989) (R: AAGGAGGTGATCCAGCCGCA). The PCR cycling conditions were $94^{\circ} \mathrm{C}$ for 5 min; 40 cycles of $94^{\circ} \mathrm{C}$ for $30 \mathrm{~s}, 60^{\circ} \mathrm{C}$ for $30 \mathrm{~s}$, and $72^{\circ} \mathrm{C}$ for $1 \mathrm{~min}$; and a final step at $72^{\circ} \mathrm{C}$ for $5 \mathrm{~min}$. The PCR was performed with approximately $50 \mathrm{ng}$ of DNA template, $100 \mathrm{nM}$ each dNTP, $5 \mu \mathrm{L}$ of $10 \times$ buffer, $75 \mathrm{mmol} / \mathrm{L} \mathrm{MgCl}_{2}$, $20 \mathrm{pmol} / \mathrm{L}$ of each primer, and $2.5 \mathrm{U}$ of Platinum Taq DNA polymerase (Invitrogen, Carlsbad, CA). Amplification was performed in a thermocycler (Aeris Thermal Cycler, Esco Micro Pte. Ltd., Singapore), and the PCR-amplified DNA samples were loaded onto a $1 \%$ agarose gel (Invitrogen) and subjected to electrophoresis for $1 \mathrm{~h}$ at a constant voltage of $90 \mathrm{~V}$. The gels were stained with $0.2 \mathrm{mg} / \mathrm{mL}$ ethidium bromide solution for $20 \mathrm{~min}$ before visualization. Images were saved after UV transillumination.

The amplicons of the ITS region were subjected to restriction with $2 \mathrm{U}$ of the enzyme HhaI (Invitrogen) using the reaction protocol described by the manufacturer (https://assets.thermofisher.com/TFS-Assets/LSG/ manuals/Anza59_HhaI_PI.pdf). The amplified DNA and enzyme mixtures were incubated for $1 \mathrm{~h}$ at $37^{\circ} \mathrm{C}$ in a thermocycler. Restriction products were subjected to agarose gel electrophoresis $(1.5 \%)$ for $1 \mathrm{~h}$ at a constant voltage of $70 \mathrm{~V}$. The gels were stained with $0.2 \mathrm{mg} / \mathrm{mL}$ ethidium bromide and documented.

The amplification profiles of the ITS regions of each isolate, together with the HhaI restriction product, were used as genomic variables to construct a dendrogram of phylogenetic similarity (Ranjard et al., 2001) using Bionumerics v. 1.50 software (Applied Mathematics, Kortrijk, Belgium). The similarity matrix Dice coefficient (Dice, 1945) and the unweighted pair group mean algorithm (Sneath and Sokal, 1973) were used.
To determine clusters, a minimum of $60 \%$ phylogenetic similarity was used.

A representative sample from each cluster was selected for partial amplification of the 16S rRNA gene using the primers and conditions described by Osborne et al. (2005). The products of this PCR were purified (PureLink Genomic DNA Purification Kit, Invitrogen) and quantified (Qubit dsDNA HS Assay Kit, Invitrogen) for DNA sequencing using the Sanger method (ABI 3500 Genetic Analyzer, Applied Biosystems, Foster City, CA), which was completed in both directions.

The quality of the sequences was evaluated by the software BioEdit v. 7.2.5 (Hall, 1999), and the consensus sequences were generated by CAP 3 (Huang and Madan, 1999). These sequences were individually aligned using Clustal $\mathrm{W}$ and the representative sequences of each genus available in the Ribosomal Database Project, and genetic similarity was analyzed via the neighbor-joining method and the Tamura-Nei model using 1,000 bootstrap replications in the MEGA v. 7.0 software (Kumar et al., 2016).

The mean ( \pm standard deviation) psychrotrophic counts of the 3 batches of raw, preheated, and bactofuged milk were $3.08( \pm 1.69) \times 10^{6}, 193( \pm 232)$, and $20( \pm 26) \mathrm{cfu} / \mathrm{mL}$, respectively.

Preheated milk was the immediate condition before bactofugation and we observed a reduction of $89.66 \%$ in the psychrotrophic count between bactofuged and preheated milk $(P<0.001)$. Kosikowski and Fox (1968) showed that bactofugation of milk decreased bacterial numbers by $95.3 \%$. They were the first to demonstrate the effect of bactofugation in the control of the microbiological quality of milk. The preheating for bactofugation $\left(\approx 55^{\circ} \mathrm{C}\right)$ alone was able to reduce the psychrotroph counts in raw milk by $99.99 \%$. This is probably related to the predominance of thermolabile microorganisms.

In our analysis of microbial diversity, 64 psychrotrophic isolates were recovered: 46 from the 3 raw milk samples, 8 from the preheated samples, and 10 from the bactofuged milk samples. The dendrograms of genetic similarity between the isolates are shown in Figures 1 and 2; it can be seen that the isolates of the raw, preheated, and bactofuged milk were grouped into 14, 5 , and 4 clusters, respectively, considering $60 \%$ genetic similarity.

Considering the identification by genetic similarity with the type species of the genus, microbial diversity is presented in Table 1. Lysinibacillus fusiformis was the most isolated species of psychrotroph in raw milk, accounting for almost half of the isolates. Lysinibacillus fusiformis is a sporulated microorganism isolated from milk (Coorevits et al., 2008), and it is expected to exhibit thermal resistance to preheating. Proportionally, it was also the most frequent species remaining after the 


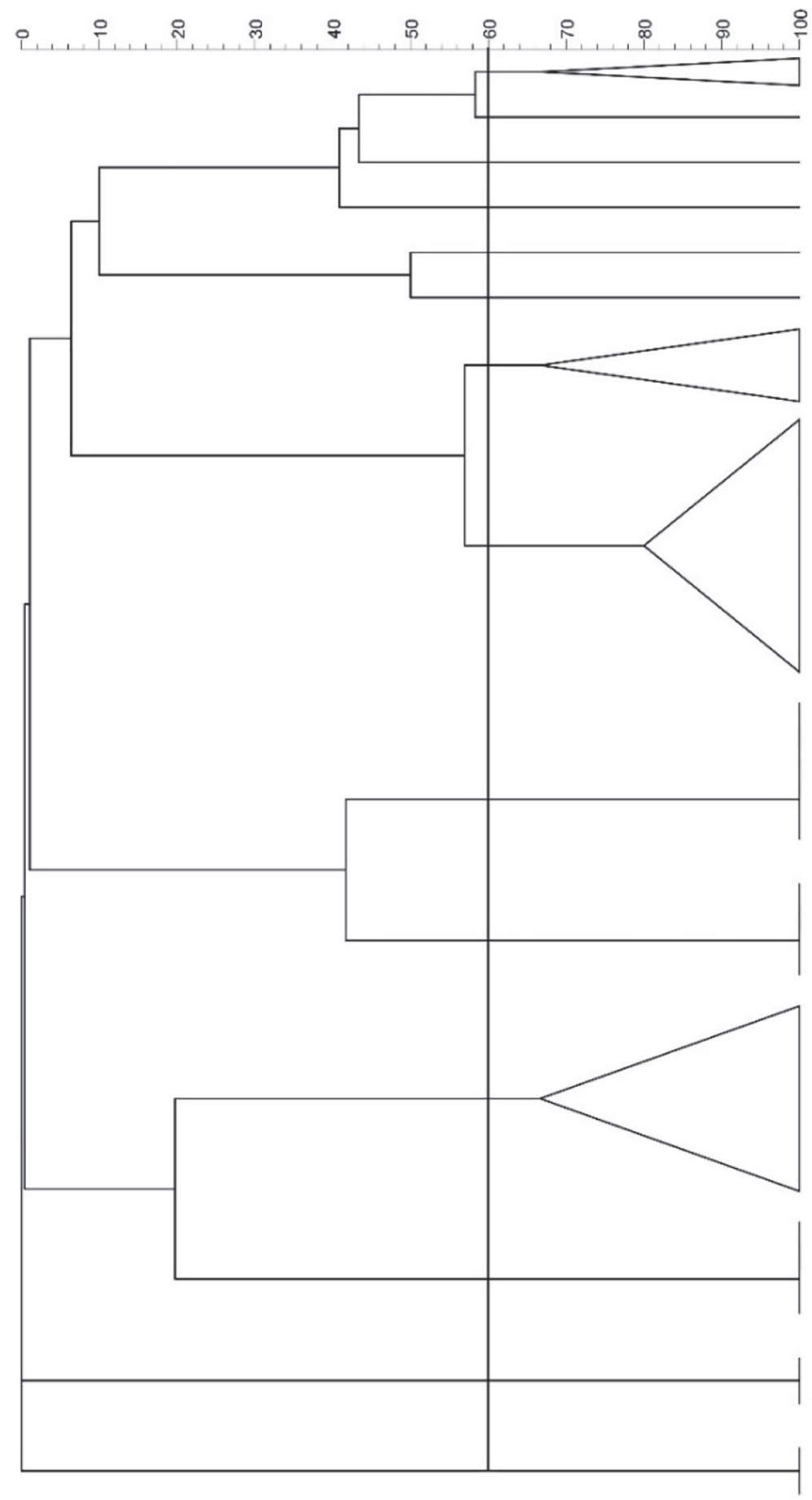

ITS

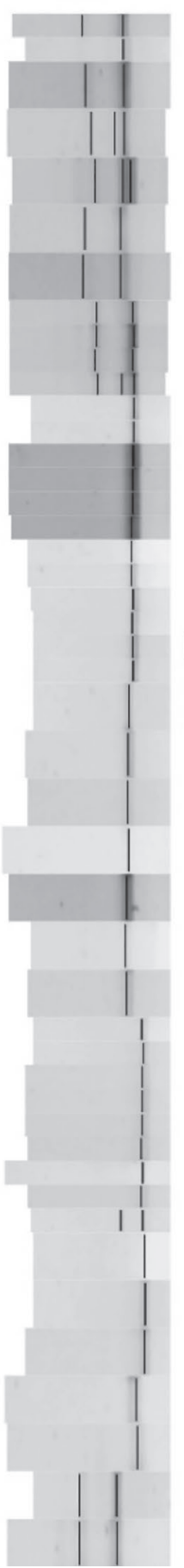

Hhal

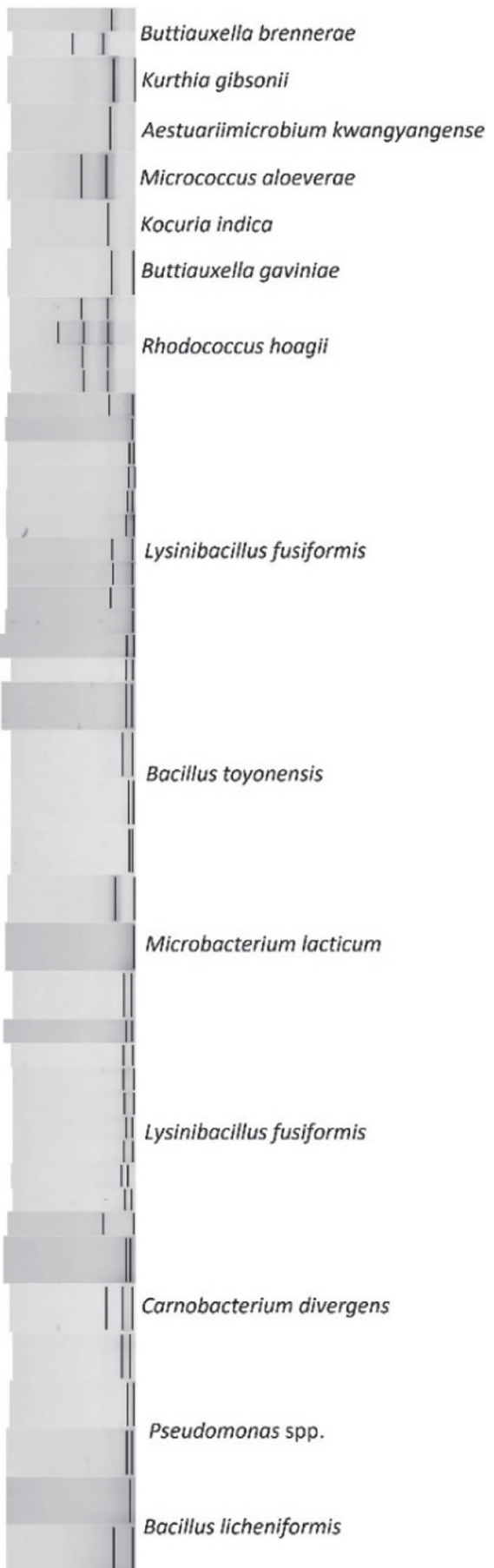

Figure 1. A genetic similarity dendrogram of psychrotrophic bacteria isolated from Brazilian raw milk, using the variables of the amplification profile of the internal transcribed spacer (ITS) region 16-23S and its restriction profile with the enzyme HhaI. The vertical line represents the minimum percentage of similarity $(60 \%)$ used to determine the 14 clusters.

bactofugation process (60\%; Table 1). Because isolates of this species have proteolytic and lipolytic potential (De Jonghe et al., 2010), any failure in storage conditions will compromise the quality of the bactofuged milk and associated cheeses, even under refrigerated conditions.

Pseudomonas spp. are considered the main psychrotrophs of raw milk in several countries (Sørhaug and 
A
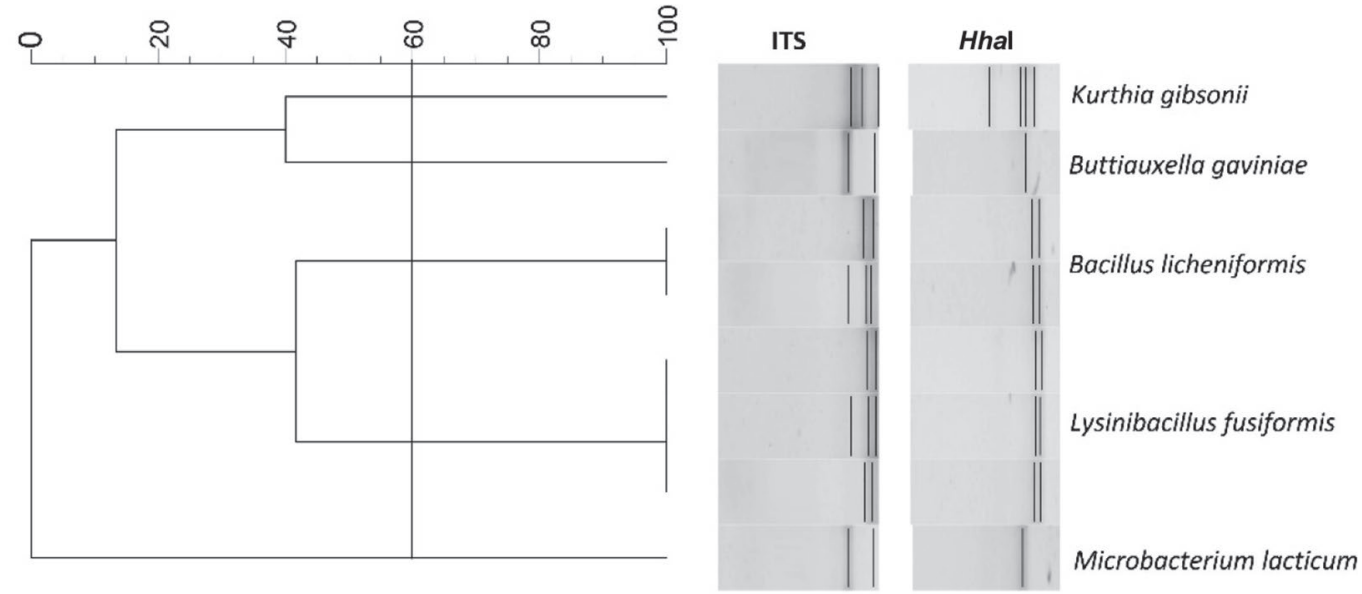

B

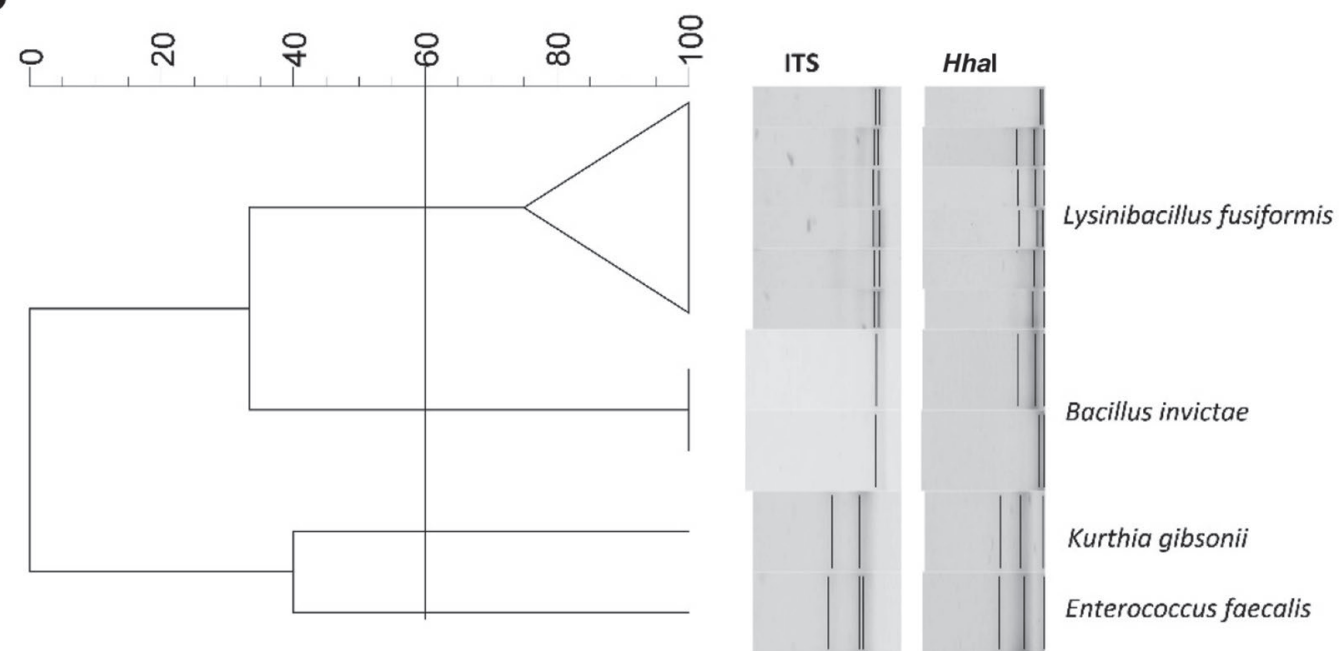

Figure 2. A genetic similarity dendrogram of psychrotrophic bacteria isolated from (A) preheated and (B) bactofuged milk, using the variables of the amplification profile of the internal transcribed spacer (ITS) region 16-23S and its restriction profile with the enzyme HhaI. The vertical line represents the minimum percentage of similarity $(60 \%)$ used to determine the clusters.

Table 1. Genetic diversity and proportionality [number (\%)] of psychrotrophs isolated from 3 Brazilian milk batches at different stages of the process (raw, preheated, and bactofuged)

\begin{tabular}{lccc}
\hline Species identification & Raw & Preheated & Bactofuged \\
\hline Lysinibacillus fusiformis & $21(45.7)$ & $3(37.5)$ & $6(60)$ \\
Bacillus toyonensis & $4(8.7)$ & - & - \\
Rhodococcus hoagii & $4(8.7)$ & - & - \\
Carnobacterium divergens & $3(6.5)$ & $1(12.5)$ & - \\
Microbacterium lacticum & $3(6.5)$ & $2(25)$ & - \\
Bacillus licheniformis & $2(4.3)$ & - & - \\
Buttiauxella brennerae & $2(4.3)$ & - & - \\
Pseudomonas spp. & $2(4.3)$ & $1(12.5)$ & - \\
Aestuariimicrobium kwangyangense & $1(2.2)$ & - & - \\
Buttiauxella gaviniae & $1(2.2)$ & - & - \\
Kocuria indica & $1(2.2)$ & - & $1(10)$ \\
Kurthia gibsonii & $1(2.2)$ & - & - \\
Micrococcus aloeverae & - & & $2(20)$ \\
Enterococcus faecalis & & & \\
Bacillus invictae & & & - \\
\hline
\end{tabular}


Stepaniak, 1997; Marchand et al., 2009; Caldera et al., 2016; Vithanage et al., 2016; Xin et al., 2017). In Brazilian raw milk, we showed that Pseudomonas do not predominate (Ribeiro Júnior et al., 2018a). In the microbiota evaluated in the present work, Pseudomonas represented only $4.3 \%$ of raw milk psychrotrophs (Table 1), and the preheating process was sufficient to eliminate these microorganisms, as was also reported by Dogan and Boor (2003). Their proteases and lipases, however, are thermostable (Bagliniere et al., 2013) and may remain in bactofuged milk.

We previously described Kurthia gibsonii as a proteolytic and lipolytic psychrotrophic of Brazilian refrigerated raw milk (Ribeiro Júnior et al., 2018a). Bacillus invictae and Enterococcus faecalis, which were identified as psychrotrophic remnants of bactofugation in the present study, are thermoduric microorganisms with proteolytic and lipolytic potential recently described by our group (Ribeiro Júnior et al., 2018b). Thus, even if pasteurization is applied following bactofugation, these microorganisms can survive.

Additionally, because counts of psychrotrophs in raw milk were high $\left(>10^{6}\right)$, it is likely that the quality of pasteurized bactofuged milk was impaired by the large amounts of thermostable microbial proteases and lipases remaining in the raw milk (Cousin, 1982). The cheese factory itself has reported problems with late proteolysis over the life of the products, even without expressive isolation of proteolytic bacteria in the final product.

As an alternative to minimize the residual deteriorating effect of these enzymes, some researchers have suggested a process of gravitational separation of microorganisms and microbial spores of milk (Caplan et al., 2013; Geer and Barbano, 2014). Because gravitational separation does not involve cellular lysis, there is no release of the enzymes from the interior of the bacteria. During bactofugation, preheating and the application of gravitational force may promote cellular lysis (Kosikowski and Fox, 1968).

Bacillus licheniformis was isolated among the psychrotrophs in raw and preheated milk but was not identified in bactofuged milk. Bacillus licheniformis is a major thermoduric (Ribeiro Júnior et al., 2018b), spore-forming species (Ribeiro Júnior et al., 2018c) in milk in Brazil and other countries (Reginensi et al., 2011; Yuan et al., 2012; Martinez et al., 2017). Thus, bactofugation appears to be effective in reducing $B$. licheniformis, which is important for the quality of processed milk. However, as other spore-forming bacteria remained following bactofugation (L. fusiformis and $B$. invictae), we cannot state that there is no risk of isolation of B. licheniformis in bactofuged milk.
The process of preheating raw milk before bactofugation is sufficient to considerably reduce the count and diversity of raw milk psychrotrophs. Bactofugation apparently has no effect on any particular group or genus of psychrotrophs. However, it was able to further reduce bacterial counts compared with preheating alone. Thus, bactofugation can be used to reduce the psychrotrophic bacterial counts of raw milk, especially before refrigerated storage in dairy factories, minimizing bacterial multiplication and the production of thermostable deteriorating enzymes.

\section{ACKNOWLEDGMENTS}

This study was supported by the following Brazilian institutes: National Council of Scientific and Technological Development (CNPq; grant number 305062/2015-8), Brazilian Federal Agency for Support and Evaluation of Graduate Education (CAPES; process 88887.145705/2017-00), Financing of Studies and Projects (FINEP), and the Araucaria Foundation (FAP/PR). The authors are grateful for the collaboration of researchers Elis Lorenzetti (Laboratory of Animal Virology, UEL) for support in molecular biology and Renan Augusto Ribeiro (EMBRAPA-Soy unity) for training the team in the Bionumerics software.

\section{REFERENCES}

Bagliniere, F., A. Mateos, G. Tanguy, J. Jardin, V. Briard-Bion, F. Rousseau, B. Robert, E. Beaucher, J. L. Gaillard, C. Amiel, G. Humbert, A. Dary, and F. Gaucheron. 2013. Proteolysis of ultra high temperature- treated casein micelles by AprX enzyme from Pseudomonas fluorescens induces their destabilisation. Int. Dairy J. 31:55-61. https://doi.org/10.1016/j.idairyj.2013.02.011.

Caldera, L., L. Franzetti, E. Van Coillie, P. de Vos, P. Stragier, J. de Block, and M. Heyndrickx. 2016. Identification, enzymatic spoilage characterization and proteolytic activity quantification of Pseudomonas spp. isolated from different foods. Food Microbiol. 54:142-153. https://doi.org/10.1016/j.fm.2015.10.004.

Caplan, Z., C. Melilli, and D. M. Barbano. 2013. Gravity separation of fat, somatic cells, and bacteria in raw and pasteurized milks. J Dairy Sci. 96:2011-2019. https://doi.org/10.3168/jds.2012-6006.

Coorevits, A., V. De Jonghe, J. Vandroemme, R. Reekmans, J. Heyrman, W. Messens, P. D. Vos, and M. Heyndrickx. 2008. Comparative analysis of the diversity of aerobic spore-forming bacteria in raw milk from organic and conventional dairy farms. Syst. Appl. Microbiol. 31:126-140. https://doi.org/10.1016/j.syapm.2008.03 .002 .

Cousin, M. A. 1982. Presence and activity of psychrotrophic microorganisms in milk and dairy products: A review. J. Food Prot. 45:172-207. https://doi.org/10.4315/0362-028X-45.2.172.

De Jonghe, V., A. Coorevits, J. De Block, E. Van Coillie, K. Grijspeerdt, L. Herman, P. D. Vos, and M. Heyndrickx. 2010. Toxinogenic and spoilage potential of aerobic spore-formers isolated from raw milk. Int. J. Food Microbiol. 136:318-325. https://doi.org/10 .1016/j.ijfoodmicro.2009.11.007.

Dice, L. R. 1945. Measures of the amount of ecologic association between species. Ecology 26:297-302. https://doi.org/10.2307/ 1932409 . 
Dogan, B., and K. J. Boor. 2003. Genetic diversity and spoilage potentials among Pseudomonas spp. isolated from fluid milk products and dairy processing plants. Appl. Environ. Microbiol. 69:130-138. https://doi.org/10.1128/aem.69.1.130-138.2003.

Edwards, U., T. Rogall, H. Blöcker, M. Emde, and E. C. Böttger. 1989. Isolation and direct complete nucleotide determination of entire genes. Characterization of a gene coding for $16 \mathrm{~S}$ ribosomal RNA. Nucleic Acids Res. 17:7843-7853. https://doi.org/10.1093/ nar/17.19.7843.

Farkye, N. Y. 2004. Cheese technology. Int. J. Dairy Technol. 57:9198. https://doi.org/10.1111/j.1471-0307.2004.00146.x.

Geer, S. R., and D. M. Barbano. 2014. The effect of immunoglobulins and somatic cells on the gravity separation of fat, bacteria, and spores in pasteurized whole milk. J. Dairy Sci. 97:2027-2038. https://doi.org/10.3168/jds.2013-7629.

Gésan-Guiziou, G. 2010. Removal of bacteria, spores and somatic cells from milk by centrifugation and microfiltration techniques. Pages 349-372 in Improving the Safety and Quality of Milk: Milk Production and Processing. Woodhead Publishing Series. https://doi .org/10.1533/9781845699420.4.349.

Hall, T. A. 1999. BioEdit: A user-friendly biological sequence alignment editor and analysis program for Windows 95/98/NT. Nucl. Acids Symp. Ser. 41:95-98.

Huang, X., and A. Madan. 1999. CAP3: A DNA sequence assembly program. Genome Res. 9:868-877. https://doi.org/10.1101/gr.9.9 .868 .

Kosikowski, F. V., and P. F. Fox. 1968. Low heat, hydrogen peroxide and bactofugation treatments of milk to control coliforms in Cheddar cheese. J. Dairy Sci. 51:1018-1022. https://doi.org/10.3168/ jds.S0022-0302(68)87116-4.

Kumar, S., G. Stecher, and K. Tamura. 2016. MEGA7: Molecular Evolutionary Genetics Analysis version 7.0 for bigger datasets. Mol. Biol. Evol. 33:1870-1874. https://doi.org/10.1093/molbev/ msw054.

Marchand, S., K. Heylen, W. Messens, K. Coudijzer, P. De Vos, K. Dewettinck, L. Herman, J. De Block, and M. Heyndrickx. 2009. Seasonal influence on heat-resistant proteolytic capacity of Pseudomonas lundensis and Pseudomonas fragi, predominant milk spoilers isolated from Belgian raw milk samples. Environ. Microbiol. 11:467-482. https://doi.org/10.1111/j.1462-2920.2008.01785.x.

Martinez, B. A., J. Stratton, and A. Bianchini. 2017. Isolation and genetic identification of spore-forming bacteria associated with concentrated-milk processing in Nebraska. J. Dairy Sci. 100:919-932. https://doi.org/10.3168/jds.2016-11660.

Normand, P., C. Ponsonnet, X. Nesme, M. Neyra, and P. Simonet. 1996. ITS analysis of prokaryotes, Pages 1-12 in Molecular Microbial Ecology Manual. D. L. Akkermans, J. D. Van Elsas, E. I. De Bruijn, ed., Kluwer Academic Publishers, Dordrecht, the Netherlands.

Osborne, C. A., M. Galic, P. Sangwan, and P. H. Janssen. 2005. PCRgenerated artefact from $16 \mathrm{~S}$ rRNA gene-specific primers. FEMS Microbiol. Lett. 248:183-187. https://doi.org/10.1016/j.femsle .2005.05.043.
Ranjard, L., F. Poly, J. C. Lata, C. Mougel, J. Thioulouse, and S. Nazaret. 2001. Characterization of bacterial and fungal soil communities by automated ribosomal intergenic spacer analysis fingerprints: Biological and methodological variability. Appl. Environ. Microbiol. 67:4479-4487. https://doi.org/10.1128/AEM.67.10 .4479-4487.2001.

Reginensi, S. M., M. J. González, J. A. Olivera, M. Sosa, P. Juliano, and J. Bermúdez. 2011. RAPD- 2057 based screening for sporeforming bacterial populations in Uruguayan commercial powdered milk. Int. J. Food Microbiol. 148:36-41. https://doi.org/10.1016/j .ijfoodmicro.2011.04.020.

Ribeiro Júnior, J. C., A. M. de Oliveira, F. G. Silva, R. Tamanini, A. L. M. de Oliveira, and V. Beloti. 2018a. The main spoilagerelated psychrotrophic bacteria in refrigerated raw milk. J. Dairy Sci. 101:75-83. https://doi.org/10.3168/jds.2017-13069.

Ribeiro Júnior, J. C., R. Tamanini, A. L. M. de Oliveira, A. A. Alfieri, and V. Beloti. 2018b. Genetic diversity of thermoduric spoilage microorganisms of milk from Brazilian dairy farms. J. Dairy Sci. 101:6927-6936. https://doi.org/10.3168/jds.2017-13948.

Ribeiro Júnior, J. C., R. Tamanini, A. L. M. de Oliveira, J. Ribeiro, and V. Beloti. 2018c. Spoilage potential of spore-forming bacteria from refrigerated raw milk. Semin. Cienc. Agrar. 39:2049-2058. https://doi.org/10.5433/1679-0359.2018v39n5p2049.

Ribeiro Júnior, J. C., R. Tamanini, B. F. Soares, A. M. de Oliveira, F. G. Silva, F. F. da Silva, N. A. Augusto, and V. Beloti. 2016. Efficiency of boiling and four other methods for genomic DNA extraction of deteriorating spore-forming bacteria from milk. Semin. Cienc. Agrar. 37:3069-3078. https://doi.org/10.5433/1679-0359 2016v37n5p3069.

Sneath, P. H., and R. R. Sokal. 1973. Numerical Taxonomy: The Principles and Practice of Numerical Classification. W. H. Freeman and Company, San Francisco, CA

Sørhaug, T., and L. Stepaniak. 1997. Psychrotrophs and their enzymes in milk and dairy products: quality aspects. Trends Food Sci. Technol. 8:35-41. https://doi.org/10.1016/S0924-2244(97)01006-6.

Stack, A., and G. Sillen. 1998. Bactofugation of liquid milks. Nutr. Food Sci. 98:280-282. https://doi.org/10.1108/00346659810224217.

Vithanage, N. R., M. Dissanayake, G. Bolge, E. A. Palombo, T. R. Yeager, and N. Datta. 2016. Biodiversity of culturable psychrotrophic microbiota in raw milk attributable to refrigeration conditions, seasonality and their spoilage potential. Int. Dairy J. 57:8090. https://doi.org/10.1016/j.idairyj.2016.02.042.

Xin, L., Z. Meng, L. Zhang, Y. Cui, X. Han, and H. Yi. 2017. The diversity and proteolytic properties of psychrotrophic bacteria in raw cows' milk from North China. Int. Dairy J. 66:34-41. https:// doi.org/10.1016/j.idairyj.2016.10.014.

Yuan, D. D., G. C. Liu, D. Y. Ren, D. Zhang, L. Zhao, C. P. Kan, Y. Z. Yang, W. Maa, Y. Li, and L. B. Zhang. 2012. A survey on occurrence of thermophilic bacilli in commercial milk powders in China. Food Control 25:752-757. https://doi.org/10.1016/j .foodcont.2011.12.020. 